

\title{
BACKGROUND TO THE ESTABLISHMENT OF THE TERRITORY OF IOWA
}

\author{
By O. E. KLINGAMAN
}

Joliet, an agent of the French government, and Marquette, a Jesuit missionary, were the first white men to look upon what is now Iowa. They descended the Wisconsin River and on June 17, 1673, entered the Mississippi nearly opposite the present site of McGregor. The Mississippi at that point is walled in "by picturesque bluffs, with lofty limestone esearpment, whose irregular outline looks like a succession of the ruined castles and towers of the Rhine." They turned southward, "floating leisurely along by day and resting at anchor in midstream at night." A landing on Iowa soil was made near the mouth of the Des Moines River, where a meeting was held with a band of Indians, probably from the tribe known as Illinois.

The next white men to visit Iowa were Frenchmen also. They were Michel Aceau and his two companions, Antoine Augel and Father Louis Hennepin, who came to the Mississippi by way of the Illinois River, having started from the site of Peoria on February 29, 1680, to explore the upper course of the Mississippi. High water and floating ice impeded their progress; it was the last of March before they passed beyond the northern boundary of Iowa. On their return voyage they descended the river to the mouth of the Wiseonsin, ascended that stream to the portage which led to the Fox River, thence down the Fox to Green Bay and returned to Canada via the Great Lakes.

The French could enter the Mississippi by two routes: the one just described; the other being by way of Lake Michigan, the Chicago River, and a portage into the headwaters of the Illinois. Trading with the Indians was profitable, and other Frenchmen went up and down the Mississippi along Iowa's shore, giving names to many places. Thus the Des Moines River was named; a place of debarkation in what is now Guttenberg in Clayton County was named Prairie La Porte. 
Across the river, almost opposite the mouth of the Wapsipinieon, is a slough through which in high water, the Mississippi overflowed in the Rock River a few miles to the eastward. 'The French named this great slough "Marias d' Osier" meaning the "Swamp of the Willows." It still bears this name on the official maps of the river.

By the treaty of 1763 which ended what is known in our history textbooks as the French and Indian War, France lost all her American possessions, save two small islands near Newfoundland. England was given Canada as known then and what is now the United States as far west as the east bank of the Mississippi and south to what then was known as Florida. Spain secured Florida and all west of the Mississippi.

In 1783 the Revolutionary War was terminated by a treaty of peace which gave the United States all the territory in America given to England by the treaty of 1763 , outlined above, except Canada.

Some of the thirteen original colonies had charters which gave them claims to that part of the United States lying west of the Alleghenies, north of the Ohio and extending to the east bank of the Mississippi. On May 11, 1786, the last of these claims was ceded to the federal government then operating under the Articles of Confederation, thus establishing the public domain with the land titles resting in the government of the United States but with the right of Indian inhabitants thereon to occupancy until this right was extinquished by the federal government. The territory set up under this land cession was known as the Northwest Territory.

Four things grew out of these land cessions: a public domain, a land survey, an Indian policy, and most important of all, the right of the federal government to create States from the public domain and admit these States into the Union.

The Land Ordinance of 1785 was enacted by the Continental Congress under the title, "An Ordinance for ascertaining the mode of disposing of lands in the Western territory," which applied only to such land as had been ceded by the individual states to the United States, and which also had been purchased by the United States from the Indians claiming it. This ordinance provided for a system of land-survey, whereby "the sur- 
veyors ... shall proceed to divide the said territory into townships 6 miles square by lines running due north and south, and others erossing these at right angles, as near as may be." It established a baseline and what is now known as a principal meridian; a system of numbering these surveyed townships was provided. The township itself was to be subdivided "into lots of one mile square or 640 acres," which were to be numbered from 1 to 36 . This system, with modifications, was later applied to all public domain aequired by the federal government. It provided for "base-lines; boundaries carefully run, measured, and marked aceording to a uniform plan: the sixmile township and the section, maps and plats, deeds and records." Later the law provided that the "section" should be subdivided into four equal divisions, known as "quartersections."

Treaties were made with the Indians in the Northwest Territory, which were later repudiated by them, because the Indians did not wish to leave their lands. Wars with the Indians kept down emigration, but the Indians were finally subdued and later deported, some tribes being sent into what is now Iowa.

The pressure of population in this Northwest Territory and in Kentucky became so great that the free navigation of the Mississippi became imperative. Spain owned the west bank and controlled the mouth of the river. On October 1, 1800. Spain ceded to France what was known as Louisiana, and on April 30, 1803, France sold Louisiana to the United States for a little over $\$ 15,000,000$. Thus the land of Iowa passed into the control of the United States.

On the 20th of December, 1803, the United States took possession of the Louisiana Purchase by certain formalities at New Orleans. In the spring of the next year similar formalities were held at St. Louis, thus extinguishing all title to French and Spanish territory west of the Mississippi included in the Louisiana Purchase.

The territory which is now known as Iowa was Indian country at that time, and had in it the following tribes: Sauk and Foxes (the two tribes were a confederation), with their principal villages near where Rock Island now stands in Illionis, but 
who claimed the southern half of the state as far west as the Missouri; the Iowa tribe along the Missouri River, but who were moving eastward; and various bands of the Sioux held the balance of what is now our state. Although the Mascountines in Iowa were few in number, the eity and county of Muscatine are named for these Indians.

At the time of the purchase of Louisiana in 1803 , no definite information of the territory itself, except for that part which we now know as the state of Louisiana, was available. Thomas Jefferson, then President of the United States, decided that an exploring party should be sent up the Missouri River to obtain all the information possible. He selected Captain Meriwether Lewis and Captain William Clark as joint commanders, and assigned a company of forty-three men to them. $\mathrm{He}$ had earefully prepared his instructions for Lewis and Clark, one of which was "to explore the Missouri River and such principal streams of it, as to determine by its course and communications with the waters of the Pacific Ocean, whether the Columbia, Oregon, Colorado, or any other river, may offer the most direct and practicable water-communication aeross the continent, for the purposes of commerce."

The men outfitted at St. Louis, leaving that harbor on May 14,1804 . They were provided with two open boats, "one with 7 oars, and one with 6 , and a large keel boat" with twenty-two oars. This boat was half-decked, fifty-five feet long. They depended upon oars for motive power, but made provision for hoisting a sail on the keel boat under favorable circumstances. On July 29, they were just south of the present site of Couneil Bluffs where they held a short conference with the Iowa Indians. On August 3, they held a friendly council with six Indian chiefs from tribes on the west side of the Missouri; it was from this couneil that the eity of Council Bluffs derives its name. The council itself, however, was held near some high hills on the Nebraska side some miles up the Missouri River. About the middle of August, they camped near the mouth of the Little Sioux River. On August 19, a young soldier, Sergeant Charles Floyd became seriously ill. He died the next day and was buried shortly thereafter on the east bank of the Missouri River, being the first white man known to have been 
buried on Iowa soil. A large monument in Sioux City marks his last resting place.

Another expedition to explore the recently acquired territory was sent up the Mississippi River under the command of Lieutenant Zebulon M. Pike. He left St. Louis on August 9,1805 , with twenty soldiers in a keel boat, seventy feet long. August 20 found them at the present site of the city of Keokuk. The river was here known as the "Rapids de Moines." Pike says, "Our boat being large and moderately loaded we found great difficulty. The rapids eleven miles long, with successive shoals extending from shore to shore across the bed of the river. The channel, which is a bad one, is on the eastern side at the first two falls. It then passes under the edge of the third, crosses to the west side and ascends that side all the way to the Sac village. . . We were met [there] by William Ewing, agent of the United States residing at the Sac village to instruct the Indians in agriculture."

After passing the mouth of the Rock River he writes, "Ten miles up the Iowa river from its mouth is a village of the Iowa Indians. From the Iowa to the Rock River we generally found beautiful prairie on the west side, and some places very rich land covered with black walnut and hickory timber. A short distance above the mouth of the Rock River, we came to the great rapids of the Mississippi which extend up the river a distance of eighteen miles. These shoals are a continuous chain of rocks reaching in some places from shore to shore. They afford much more water than the De Moines rapids, but the current is swifter, more difficult to ascend."

At the mouth of the Rock River he held a conference with the Sauk and Fox Indians who had large villages near by. He told them that they were under the control of the Great Father in Washington, and that in the future the Americans would furnish them with their necessary supplies. He gave them the American flag to raise, and told them to pull down the British flag, but the Indians suggested that both flags should fly because "they wanted to have two fathers."

On August 31, he found "an encampment of Fox Indians on the west shore of the river which appeared to be an old 
town. It is about ninety miles above Rock Island by the river."

On September 1 he held a conference with Julien Dubuque near the lead mines, and on September 4 a council was held with the Winnebago Indians on the west shore of the Mississippi River nearly opposite the mouth of the Wisconsin. The council was held on a high hill which is now locally known as Pike's Peak. From there he continued northward on his exploration and returned to St. Louis later. He made some recommendations to the federal government as to locations of forts, for since the Indians had been aceustomed for many years to secure what they needed from British traders, it became necessary for the United States to take possession of this new purchase by military oceupaney. Forts were established on the Mississippi River at what is now Fort Madison (1808) and Fort Shelby (1813) at Prairie du Chien, Wisconsin.

The War of 1812-15 was fought in part of what is now the state of Iowa, or elose to its borders. True, the history textbooks do not speak of this. Attempts by the American military authorities at St. Louis to re-enforce and supply Ft. Shelby aroused the enmity of the Sauk and Fox Indians, and they joined the British. As a result there were two battles fought on the Mississippi River near Davenport. One resulted in the defeat of an American force from St. Louis under the command of Lieutenant Campbell on an island which is now part of East Moline, Illinois. Most of the fighting was done by the Indians assisted by several Englishmen who had one cannon which was used effectively. Lieutenant Campbell is commemorated by a monument erected on the island which bears his name. Later an attempt was made by Major Zachary Taylor, later President of the United States, to ascend the river with troops and supplies, and again a battle was fought in the vicinity of Davenport. Taylor's boats were landed on Credit Island, which is now a eity park of Davenport, where he was defeated by the Sauk and Fox Indians under Black Hawk, assisted by these same few Englishmen who had previously aided in the defeat of the Campbell, and the cannon. Fort Madison was abandoned also beeause of the Indian attacks. Some years ago the Daughters of the American 
Revolution at Davenport placed a bronze marker deseribing the defeat of Zachary Taylor on a large granite boulder which is at the entrance to Credit Island park.

The War of 1812-15 was concluded by the Treaty of Ghent, in which Great Britain secured to the Indians all their rights and possessicns which they had at the beginning of the war.

\section{Pioneer Settrens}

The states that were being made out of the old Northwest Territory were so rapidly settled that the state of Ohio was admitted to the Union in 1803, Indiana, 1816, Illinois, 1818, with waves of migration going into Michigan and what is now Wisconsin. The line of migration was definitely westward and could not be stopped by the Mississippi River. The federal government as guardians of the Indians found it necessary to establish a chain of forts along the Mississippi for the express purpose of keeping the white settlers out of the Indian territory lying north of the northern boundary of the state of Missouri and west of the Mississippi River. By this means also Indian warfare was kept to a minimum. The following forts were established: Fort Edwards, 1815, Fort Armstrong on Rock Island, 1816, Fort Crawford at Prairie du Chien, 1816 (Fort Shelby had been destroyed in the late war), and Fort Snelling in 1819 near the mouth of the Minnesota River.

Some settlers were on the west bank of the Mississippi River prior to the establishment of these forts. Louis Honore Tesson (1799) settled on the present site of Montrose and is famed in history for having set out the first apple orehard in Iowa, but its site is no longer visible because the dam at Keokuk raised the waters of the Mississippi so high that the site of the famous apple orehard is now submerged.

Another early settler, Bazil Giard, sent a petition on October 15, 1800, to Delassus, Governor of Upper Louisiana:

Bazil Giard's petition.-To Charles Dehault Delassus, Lieutenant Colonel of the Spanish troops \& Governor of Upper Louisiana and its dependeneies, \&e, \&c. Humbly shows that your most obedient servant, the named Bazil Giard, subject of his Catholie Majesty, has since fifteen years, oceupied a tract of land, situated about half a league from the river Mississippi, and has constructed buildings thereon, and made con- 
siderable expenses to improve the said land-The petitioner, who has a wife and three children, humbly asks from your goodness the concession for the said land, according to the privileges granted to the faithful subjects of his Catholic Majesty; and your petitioner, respectfully requests that you will inform yourself from the Citizens of St. Louis as to his Conduct and Character, since he became a subject of the King of Spain; and he hopes that said information will be such as to justify you in Granting his demand-and your petitioner shall feel it his duty, ever to pray for the preservation of your person. With all eonsideration and respect, your obedient servant.

Prairie Du Chien, October 15th, 1800.

BAZIL GIARD.

\section{Delassus answered favorably :}

Saint Louis of Illinois, this 20th of November 1800-We Don Charles Dehault Delassus, Lieutenant Colonel of the armies of H. C. M. and Lieutenant Governor of the Western part of Illinois and dependencies \&e- In virtue of the satisfactory reports to us made, as to the good conduct of the petitioner, and his fidelity to the Spanish Government since he is settled upon the domain of H. C. M.-do grant his demands, in order that he may peacefully enjoy his property, as well himself as his heirs, until he applies for the concession to my lord the Intendant by handing to us his petition, wherein he shall specify the number of arpens of land, he is settied upon, in order that a regular title may be furnished him, similar to all those which are granted in the name of H. C. M. to his faithful subjects.-And moreover, we recommend to the said petitioner to help with all means in his power, the travellers who should pass at his house, as he has done hitherto-and to preserve a good understanding between the Indian nations and our government, as well as to inform us with the greatest eare of all the news which he shall gather, and which could affect the peace and property of our settlements. Done by us, in the Hall of our Government, the day and year as above-in faith whereof we have signed and affixed our seal.

CHARLES D. DELASSUS.

This grant that Giard received consisted of $6808 \frac{1}{2}$ arpens, which, translated into our system of land measurement is equal to 5,760 acres. In 1808 this elaim was contested but was confirmed by the United States government on the condition that the Indian rights be extinguished.

Julien Dubuque, on September 22, 1788, secured a concession from the Fox Indians to mine lead on the site of the present city of Dubuque. Dubuque employed the Indian women and the old men to work in the mines from a Fox village near the site of the city, then known as the village of Kettle Chief; 
it had about 400 people, of which 100 were warriors. He also earried on an extensive business as a trader with the Indians. He had what may be called a "shadow of" a title" from the Spanish government, but it was not accepted by the United States when the United States assumed jurisdiction over the country. His death oceurred in 1810 . He was buried on a bluff near the river, at the present time a beautiful monument marks his last resting place.

Colonel George Davenport likewise was an independent Indian trader with headquarters on Rock Island, 1816, later selling to the American Fur Company. Davenport also established a trading post on the Cedar River above the mouth of Rock Creek, which was continued until 1835. Many of the furs traded to George Davenport were from animals in this territory eaught ehiefly by the Sauk and Foxes. The eity of Davenport was named by Antoine Le Claire after Colonel George Davenport.

The American Fur Company in 1808 had a trading post in what was then known as Flint Hills, now Burlington. The French trader, Le Moliere, established a trading post in 1820 on the Iowa side of the river about six miles above Keokuk on the Des Moines River.

In 1820 Dr. Samuel C. Muir, "a surgeon in the United States army, crossed the river and built a cabin where Keokuk now stands. He had married a beautiful and intelligent Indian girl of the Sauk nation and their house was on a little Iowa farm where the cabin stood." Later the War department issued an order compelling the army officers of the frontier posts to abandon their Indian wives. Dr. Muir refused to obey this order and was forced out of the army. He died at his home on the banks of the Mississippi in 1832.

In 1830 a trading post near Poweshiek's village was established on the Iowa River below the present site of Iowa City.

Summing up, until 1833 it was unlawful for settlers to be in what is now Iowa, beeause the Indian titles to the land had not been extinguished, and while the United States exercised jurisdiction over it, it was bound by its Indian poliey to refrain from selling any land therein until the Indian title had been extinguished. 


\section{Earicy Iowa Indian Treaties}

As early as 1825 the federal government made an attempt to check the war activities of the Sauk and Fox and the Sioux tribes in what is now northeastern Iowa. On August 19, 1825, the Indians made a treaty with the United States in which a beundary line was set up between these nations, which was to be ratified by a council that should be held with the Yancton band of the Sioux in 1826, and also with the Ottoes, for the purpose of ratification of this treaty, these tribes not being represented in the council of 1825 . However, the council of 1826 was never held. Since an imaginary line marking a boundary proved insufficient to keep these tribes from going to war, another council was held at Prairie du Chien on July 15, 1830. The following tribes were represented: "Sauk and Fox, Medewakantan, Wahpetuka, Wahpeton, and Sisseton bands of the Sioux, Omaha, Iowa, Oto and Missouri.",

At this council, the Sauk and Foxes agreed to cede and relinquish to the United States "forever" a tract of country. twenty miles in width, and the Sioux agreed to cede and relinquish to the United States "forever" a similar tract of land, these two tracts to adjoin each other, making a neutral country forty miles wide stretching from the Mississippi to the Des Moines River.

The west end of the line dividing this forty mile strip into two equal parts (the northern part eeded by the Sioux and the southern part by the Sauk and Foxes), was on the east side of the Des Moines River at high water mark, probably in Section 19, Township 91, North, Range 28, East, near Dakota City in Humboldt County. The east end of this line "must have been near the middle of the west side of Township No. 100, Range No. 3, on the east side of Iowa Township, Allamakee County." 'The significant fact of this treaty was not the cession of the lands on either side of the lines just mentioned, but the power given to the President of the United States by which he had the right to assign and allot the lands eeded and relinquished "to the tribes now living thereon, or to such other tribes as the president may locate thereon for hunting ; and other purposes.', 
In this same treaty all the Indians of this eomneil ceded and relinquished to the United States all claims to what is now southeastern Iowa, the outline of which was described as follows :

The line began at the upper forks of the Demoine, thenee passing the sourees of the Little Sioux and the Floyd's River, down Rock and Big Sioux rivers, thence down the Missouri to the mouth of the Kansas River, thence up along the western and northern boundary of Missouri, to the islands dividing the waters which flow into the Missouri and the Des Moines, thence northerly along said ridge to the source of the Boyer River, thence in a straight line to the place of beginning.

Thus the Indian title to most of western Iowa was extinguished before the eastern Iowa lands were given up by the red men. The Chippewa, Ottawa and Pottawattomie tribes were moved from the western shores of Lake Michigan to a tract of about five million acres in the southwestern Iowa cession, as a result of a council held in Chicago, September 27, 1833. A council at Davenport on September 15, 1832, brought about the removal of the Winnebagos in 1840 from the Fox River in Green Bay territory in what is now Wisconsin to the west side of the Mississippi, in the neutral strip. The Black Hawk War was fought in 1832 and as a result, a couneil was held by the federal government on September 21, 1832, at what is now Davenport, with the Sauk and Foxes. General Winfield Scott of the army and Governor John Reynolds of Illionis represented the federal government. By Article I of this treaty

. . . the eonfederated tribes of the Sacs and Foxes cede to the United States forever all the lands to which the said tribes have title or claim, (with the exception of the reservation hereinafter made) included within the following bounds to-wit: Beginning on the Mississippi river, at the point where the Sac and Fox Northern boundary line, as established by the second article of the treaty of Prairie du Chien, of the fifteenth of July, one thousand eight hundred and thirty, strikes said river; then up said boundary line to a point fifty miles from the Mississippi, measured on said line; thenee, in a right line to the nearest point on the Red Cedar of the Ioway, forty miles from the Mississippi river; thence, in a right line to a point in the northern boundary of the State of Missouri, fifty niles, measured on said boundary, from the Mississippi river; thence, by the last mentioned boundary to the Misissippi river, and by the western shore of said river to the place of beginning. ... . 
Art. II. Out of the cession made in the preceding article, the United States agree to a reservation for the use of the said confederated tribes, of a tract of land containing four hundred square miles, to be laid off under the directions of the President of the United States, from the boundary line crossing the Ioway river, in such manner that nearly an equal portion of the reservation may be on both sides of said river, and extending downwards, so as to include Ke-o-kuk's prineipal village on its right bank, which village is about twelve miles from the Mississippi river.

The reservation in Article II quoted above was called "Kcokuk's Reservation." "It was a tract of land extending on either side of the Iowa River down to within less than ten miles of the Mississippi, about ten miles wide, and supposed to contain 400 square miles, about one-half on either side of the Iowa River." The Government's blue print "of this survey (Keokuk's Reserve) indicates the location of Keokuk's principal village at the south end of this reservation; Wapello's village, 8 or 10 miles farther up ; and Poweshiek's village near the upper end of the reservation." Keokuk's Reserve was eventually ceded to the government by a treaty of September 28, 1836, "the Indians agreeing to remove by the first day of November."

Prior to 1832 the Sauk and Foxes eeded 119,000 acres for the use of half breeds belonging to their nations, ealled the Half Breed Tract, in Lee County. This tract lay between the Mississippi and Des Moines Rivers.

Although title to the Indian lands was passing into the hands of the federal government, these lands were not open to settlement by the whites because Congress on March 3, 1807, passed an act which forbade anyone from settling upon any lands owned by the government until such lands had been surveyed. Nevertheless, settlements were being made in this area as soon as the treaty of 1832 was ratified.

Civil law began really to operate in what is now Iowa when, by act of Congress, June 28, 1834, a large territory west of the Mississippi River was attached to the Territory of Michigan. The territory so attached is described as follows: all of North Dakota east of the Missouri and White Earth rivers, all of South Dakota east of the Missouri River, all of Minnesota west of the Mississippi River and all the present area of 
Iowa. Under Michigan's regime a number of settlements were begun at various points on the Mississippi River. It must be remembered that the rivers were the highways at that time, and consequently early settlements were made along the navigable streams.

Prairie La Porte, now Guttenberg, was founded on December 4,1839 . The first permanent settlement at Dubuque was in 1833. Miners crossed the river at earlier dates and worked in the mines, but federal troops removed them each time. Bellevue was platted in 1835 and established as a post office in 1836; Sabula was settled in 1836. Camanche dates from 1836; Lyons was platted in 1837 , a ferry system was started there shortly thereafter. A permanent settlement in the spring of 1836 was made at Elizabeth, now Princeton. Davenport was laid out on a elaim that had been filed in 1833. The town was platted in 1835. A town site company, of which Antoine Le Claire and George Davenport were members, laid out thirty-six blocks in the original plat, three of which were dedieated for public use. One of these blocks is oceupied today by the court house and the other two are playgrounds. Antoine Le Claire reserved a strip of land along the river bank for public use. As a result the city of Davenport owns its levee on which a beautiful park is situated, as well as a large parking space, and rents to some industries. Farther down the river, Buffalo was platted in 1836, although Captain Benjamin Clark was a settler there in 1833 . The first ferry in Scott County was owned by Captain Clark, the ferry running between Buffalo and Andalusia, Illinois.

Museatine, originally named Bloomington, was a trading post in 1833 and was permanently settled in the spring of 1834. Fort Madison as a settlement began its existence in 1833. The first $\log$ cabin in Keokuk, as already been mentioned, belonged to Dr. Muir, who built it in 1820. The town itself was laid out in 1837 .

The Organization of Civil Governanent

The legislative council of the Territory of Michigan passed a statute, approved September 6, 1834, that created a system of local government on the west side of the Mississippi River. The law was as follows: 
Section 1. Be it enacted by the Legislative Council of the Territory of Michigan, That all that district of country which was attached to the Territory of Miehigan, by the act of Congress entitled "An act to attach the territory of the United States west of the Mississippi river and north of the State of Missouri to the Territory of Michigan," approved June twenty-eight, eighteen hundred and thirty-four, and to which the Indian title has been extinguished, which is situated to the north of a line to be drawn due west from the lower end of Rock Island to Missouri river, shall constitute a eounty, and be ealled Dubuque; the said county shall constitute a township, which shall be called Julien; the seat of justice shall be established at the village of Dubuque until the same shall be changed by the judges of the eounty court of said county.

Section 2. All that part of the district aforesaid, which was attached as aforesaid to the Territory of Michigan, and which is situated south of the said line to be drawn west from the lower end of Rock Island, shall constiute a county, and be called Demoine; the said county shall constitute a township, and be called Flint Hill; the seat of justice of said county shall be in such a place therein as shall be designated by the judges of the county court of said eounty.

Section 3 established a county court in each of these two counties. Section 4 is as follows :

All laws now in foree in the county of Iowa, not locally inapplieable, shall be and hereby are extended to the counties of Dubuque and Demoine, and shall be in foree therein.

Section 5 provided for an election of township officers in these two townships:

All elections in the county of Dubuque shall be held at the following places, to wit: at Lorimier's store in the village of Dubuque, and at Gehon's store in the village of Peru, at the dwelling house now occupied by Hosea T. Camp, near the head of Cat Fish creek, and at Lore's dwelling house on the Mukkoketta. Elections in the eounty of Demoine shall be held at the seat of justice of said county.

Inasmuch as the laws of the county of Iowa were extended to these counties on the west bank of the Mississippi River by Section 4 and also by Section 6 , it is necesary to know what the county of Iowa was at that time. The county of Iowa was established by the legislative council of the Territory of Michigan, by legislation approved October 9, 1829. Section 1 of that act is as follows:

Be it enacted by the Legislative Council of the Territory of Michigan, That from and after the first day of January next ensuing, all that part of the county of Crawford to which the Indian title has been extinguished, and embraced within the following boundaries, namely, beginning at the mouth of the Ouisconsin River, and following the course of 
the same, so as to inelude all the islands in said river, to the portage between the said Ouisconsin and the Fox River, thence east until it intersects the line between the counties of Brown and Crawford, as established by the proclamation of the Governor of this Territory, bearing date the twenty-sixth day of October, one thousand eight hundred and eighteen, thence south with said line to the northern boundary of Illinois, thenee west with said boundary to the Mississippi River, thenee up said river, with the boundary of this Territory, to the place of beginning, shall form a county, to be called the county of Iowa.

Michigan Territory had jurisdiction of the west bank 0 t $^{\prime}$ the river for approximately two years, or until Wisconsin Territory was organized in 1836 and given jurisdiction of all lands in what is now Wisconsin, all of Minnesota, all that part of North Dakota lying east of the White Earth River and the Missouri River, and everything that is now Iowa.

The first legislation of the Wisconsin Assembly divided old Demoines County (in this legislation Des Moines is spelled Demoines), into the following counties: Lee, Van Buren, Henry, Louisa, Musquitine, Cook, and the present Des Moines County. The western boundary line of each of these counties except Lee was fixed at the "Indian boundary line," as eivil government could not extend into territory where the Indian title to the land had not been extinguished.

It appears that the old county of Demoine had accumulated some debts, for Section 10 of this act provides :

And be it further enacted, That the proper authority of the several counties hereby established, so soon as the said counties shall beeome organized, shall liquidate and pay so much of the debt now due and unpaid by the present county of Demoines, as may be their legal and equitable proportion of the same, according to the assessment value of the taxable property which shall be made therein.

This legislation was approved December 7, 1836. On December 21, 1837, the legislation was approved which divided the old county of Du Buque and established boundaries for the following counties: Clayton, Fayette, Delaware, Buchanan, Jackson, Jones, Linn, Benton, Clinton, Cedar, Johnson, Keokuk, and the present county of Dubuque. The counties of Johnson and Keokuk were temporarily attached to and considered a part of the county of Cedar for administrative purposes. Clinton was attached to Seott in a similar manner. The counties of Jones, Linn and Benton were attached to 
Jackson County for temporary purposes, while the counties of Delaware and Buchanan were attached to Du Buque County for temporary purposes. Fayette was similarly attached to Clayton.

These statutes organizing these new counties out of the old counties of Demoine and Du Buque also provided legislation for the selection of county seats in several of these counties, as well as providing that as soon as these counties should become organized, they should pay "so much of the debt now due and unpaid by the present county of Du Buque, as may be their legal and equitable proportion of the same according to the assessment value of the taxable property which shall be made therein."

\section{LAND SuRvey}

Reference is here made to two things previously mentioned: the necessity of surveying public lands in order that the settlers might definitely locate land; and the Land Ordinance of 1785 , which provided for land surveys.

The base line for all lands in Iowa is known as the National Base Line; it extends from a point on the Mississippi River due west through Little Rock, Arkansas. From this National Base Line lines were surveyed north from points on the base line. six miles apart. These were meridian lines and were intersected by lines running east and west from some principal meridian set out in the national survey scheme. These east and west lines intersected the north and south lines at right angles so that they enclosed an area known as a township, which was, presumably, six miles square.

In designating a given township in this land survey system, the number of the township is ascertained by counting the townships from the base line to and including the certain township under question. All townships along the base line are townships No. 1. The sixty-seventh township north from said base line would be Township 67 , North. Thus, there are a number of townships that are designated 67 , North. In order to designate a particular township 67 , North, it would be necessary to ascertain its position east or west, as the case may be, from some principal meridian. 


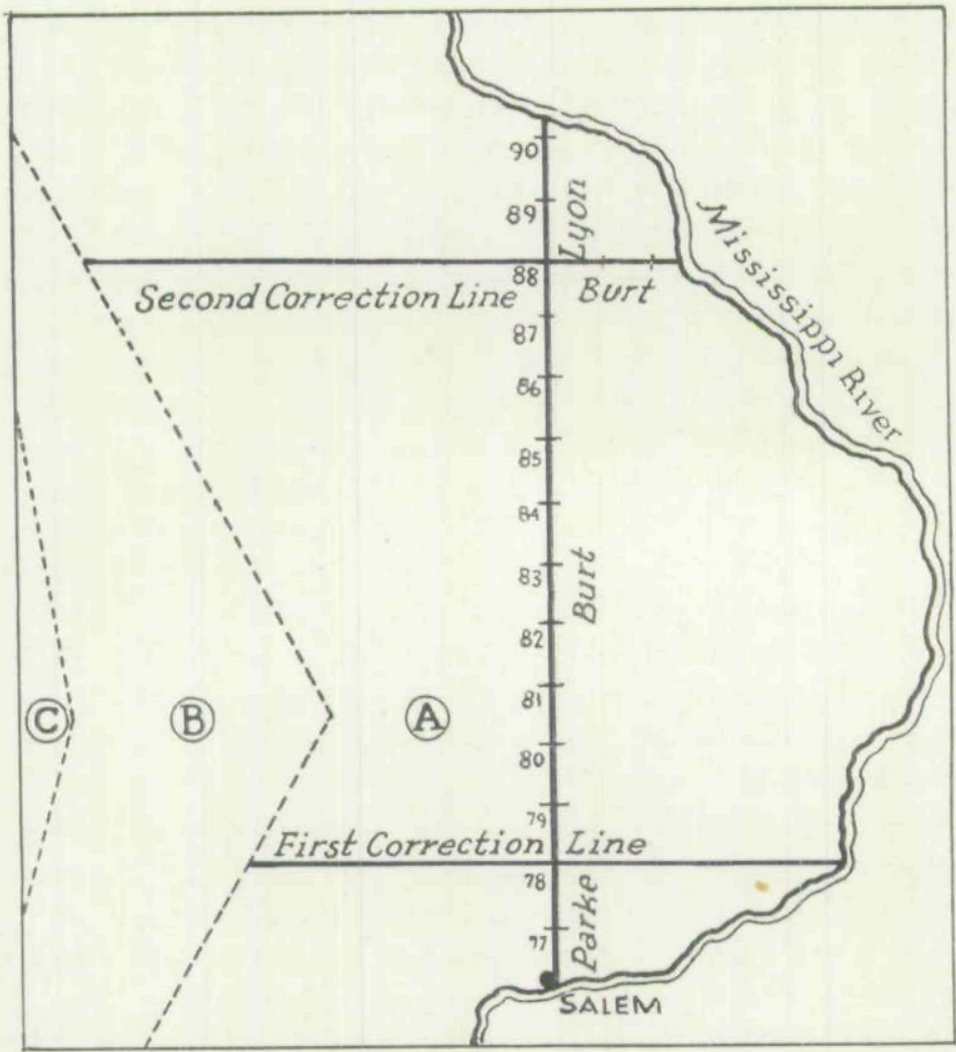

THE FIFTH PRINCIPAL MERIDLAN (NOW IN) IOWA

(A) A portion of the Black Hawk Purchase, 1832; surveyed 1836-37.

(B) A portion of the Second Purehase, 1837; surveyed 1838.

(C) The New Purchase, 1842; surveyed 1843-53. 
The principal meridian selected for Iowa is known as the Fifth Principal Meridian in the land survey scheme, and all townships are designated by range numbers as east or west of the Fifth Principal Meridian. Most of the land lying east of the Fifth Principal Meridian is, of course, in Scott and Jackson eounties, although there is some in Dubuque. The first township lying on the west side of the Fifth Principal Meridian is designated by a range number, as Range 1, West. The legal deseription of township 67 adjoining the Fifth Principal Meridian would be Township 67, North, Range 1. West of the Fifth Principal Meridian. This means that it is the sixty-seventh township north of the National Base Line, and adjoins the Fifth Principal Meridian on the west. All the southern tier of townships in the state of Iowa extending along the southern boundary of the state from the Des Moines River west, are Township 67 , North. The southernmost township in the state is Township 65, being in the extreme southeastern corner of Lee County.

Ail the townships along the northern border of the state are townships 100 . Thus, by a township number north, and a range number east, or west, as the case may be, it is easy to ascertain the location of any given piece of land, as far as the township is eoneerned.

It must be borne in mind that this township is known as a congressional township, and has nothing whatever to do with the township which is organized for political purposes and which bears a name. Each township is further subdivided into thirty-six square miles, each square mile bearing a number. These numbers run consecutively from 1 to 36 , numbering back and forth across the township, starting in the northeast corner. Thus, Section No. 1 is in the northeast corner, and Section No. 36 is in the southeast corner.

Later on it was found that this method was peculiarly adapted to two things in the state of Iowa; one was the organization of counties by placing a certain number of townships in each county; the other was the organization of the public school system for the purpose of providing educational facilities for people living in the open country, whereby four sections of land were made to constitute a school district. 
These sections of land were further subdivided by federal law into four equal parts, each known as a quarter section and designated as follows: northeast quarter section, northwest quarter section, southeast quarter section, and southwest quarter section.

The curvature of the earth, however, causes the meridian lines to converge at the North Pole, and as the survey continued northward from the National Base Line, it became difficult to keep the township six miles square. To correct this, the land survey system allowed for the insertion of correction lines running east and west. The use of these correction lines is merely to correct the error due to convergence and to start a new set of townships adjoining the correction line on the north that shall be six miles square. The numbering, however, continues consecutively, irrespective of the correction line. In Iowa there are two correction lines. If the reader will notice a map of the counties of the state of Iowa, he will see that there are jogs, or offsets, as in Audubon, Guthrie, and Polk counties. These offsets mark the First Correction Iine. The second one starts near Dubuque, at the Missisippi, passing westward near Waterloo; the town of Correctionville in the western part of the state gets its name from being located on this Second Correction Line.

When surveying the Fifth Principal Meridian, Burt established "the intersection of the First Correction Line with the Fifth Principal Meridian; the six-mile intersections on the Fifth Principal Meridian of the township lines, including that of the south boundary of Township 89 which is the Second Correction Line, then turned east and established the range lines on it to the Mississippi River.' The Fifth Principal Meridian is important in giving the legal description of lands in Iowa.

The man who surveyed most of it was William Austin Burt, who "determined its location and ran it out, marked and established it only between the first and second correction lines; that is, between the south boundaries respectively of townships 79 and 89 north. The points of beginning and ending left portions of it to be extended north fourteen miles to the Mississippi River, by Orson Lyon, and southward 
some nine miles also to the Mississippi River, which was done by Harvey Parke. . . ."

\section{LAND Titles}

When enough of the townships had been surveyed, land offices were opened and the sale of public lands began. The United States government fixed the minimum price of land at $\$ 1.25$ an acre on such lands as were first opened for settlement; in theory the lands were sold to the settlers by selling them to the highest bidder. As a matter of fact, on the day when land was to be sold, the settlers, through their "claim associations," and with a thorough understanding with the registrar of the land office, were able to secure their lands at $\$ 1.25$ an acre, the registrar allowing only one bid to be made and "knocking" the land down to the man whom he knew was the actual settler thereon, or to some person acting for him.

After the bona fide settlers who had come in illegally, but who had oceupied and improved the lands, had purchased their respective farms, the balance was sold to the highest bidder. Later on, as the Indian title became extinguished from other lands, land offices were opened elsewhere. The land was paid for in eash, that is, in specie, or its equivalent, the equivalent of specie being a "bounty land warrant." These bounty land warrants were issued for "bounty land to certain Officers and Soldiers who have been engaged in the Military Service of the United States." The issuance of this warrant was payment, in part, for services rendered by the officers and the soldiers. A warrant was issued by the United States government to the soldier or his widow; this warrant had a number and permitted the soldier to purchase public land equal in amount to forty acres, although officers were given warrants for larger amounts.

For example, Abraham Lincoln, for his services as eaptain in the Black Hawk War, was given two bounty warrants-one for forty acres under the act of 1850 and another for 120 acres under the act of 1855 . The first warrant was used in buying a forty-acre tract in Tama County on July 21, 1854, and the second warrant was used in buying 120 acres in Crawford County, September 10, 1860.

These bounty warrants were issued to the veterans of the 
wars of the Revolution, 1812-15, and the various Indian wars, or to their widows. Because they were assignable, the land speculator was able to buy a number of these at a big discount; buying these land warrants and then "entering" the land was a profitable business.

At the time of the purchase, the land purchaser was given what was ealled a patent, from the United States. All land titles in the state of Iowa run back to these so-called patents issued by the United States government. These of course could not be issued until the land had been surveyed. The following is a true and exact copy of a patent issued August 1,1854 , for forty acres of land that was sold in the Chariton land office:

\section{THE UNITED STATES OF AMERICA}

To all to whom these presents shall come, Greetings:

WHEREAS, in pursuance of the Act of Congress, September 28th, 1850, entitled "an Aet Granting Bounty Land to certain Officers and Soldiers who have been engaged in the Military Service of the United States," Warrant No. 90349 for 40 zeres issued in favor of Samuel Yerger Private, Captain Hugh's Company Pennsylvania Militia War 1812 has been returned to the General Land Office, with evidence that the same has been duly located upon the North West quarter of the North West quarter of Section thirty five in Township seventy North of Range twenty four West in the District of Lands subject to sale at Chariton, Iowa, containing forty aeres according to the Official Plat of the Survey of the said Land returned to the General Land Office, by the SURVEYOR GENERAL, Which has been assigned to Orro N. Kellogg.

NOW KNOW YE, That there is therefore granted by the United States unto the said Ozro N. Kellogg and to his heirs the tract of Land above deseribed; TO HAVE AND TO HOLD the said tract of Land, with the appurtenances thereof, unto the said Ozro N. Kellogg and to his heirs and assigns forever.

IN TESTIMONY WHEREOF, I, Franklin Pierce, PRESIDENT OF THE UNITED STATES OF AMERICA, have eaused these Letters to be made Patent and the Seal of the General Land Office to be hereunto affixed.

GIVEN under my hand at the CITY OF WASHINGTON, the first day of August in the year of our Lord one thousand eight hundred and fifty four, and of the United States the seventy-ninth.

BY THE PRESIDENT: Franklin Pierce

(Seal)

Record of Miscellaneous Military Grants, Vol. 220 Page 207
By H. E. Baldwin, Asst. Secretary. Countersigned by Acting Recorder of the General Land Office Ad Interim 
If the land was paid for in eash it had to be "hard" money, that is, gold and silver. The gold and silver coins that were legal tender at the time the first Iowa settler bought his land from the federal government, as set out in an act of Congress in 1834 and continued in force until 1857, were as follows: "The gold coins of Great Britain, Portugal, Brazil, France, Spain, Mexico and Columbia, and the silver dollars of Spain, Mexico, Peru, Chile, Central America, Bolivia, and the five-frane pieces of France." These coins had to be of full weight, for if they were under they were not aceeptable otherwise as substitutes for United States coinage.

One reason these coins were used was that our own silver coinage contained so much silver that it was worth more as bullion than as money, the result was that merchants and others receiving coins melted them into bullion which was sold at a profit. Our gold coins disappeared from eireulation for the same reason. Congress sought to remedy this situation in 1834 by reducing the gold content of the eagle, half-eagle, and the quarter eagle in order to make them circulate as money. Unfortunately the silver in the silver dollar was unchanged by this act, with the result that the silver dollar did not cireulate as money. In 1837 , however, there was a slight reduction of the amount of pure silver in the silver coins, which eonsisted of the dollar, half-dollar, quarterdollar, dime, and half-dime.

How to settle upon public lands not yet surveyed and yet to hold a good title to the claim was a constant problem to men of territorial Iowa. While the Territory of Wisconsin still had jurisdiction over Iowa the legislature of that territory passed a bill "to legalize the sale of lands owned by the government of the United States," as follows:

All contracts, promises, assumptions or undertakings, either written or verbal, which shall hereafter be made in good faith and without fraud, eollusion or cireumvention for the sale, purchase or payment of improvements made on the lands owned by the government of the United States shall be deemed valid in law or equity, and may be sued for and recovered as in other contracts.

On January 15, 1839, the legislative assembly of the Territory of Iowa enacted this same statute with an additional section as follows: 
That all deeds of quit elaim, or other conveyanee, of all improvements upon public lands, shall be as binding and effectual, in law and equity between the parties, for eonveying the title of the grantor in and to the same, as in cases where the grantor has the fee simple to the premises conveyed.

The Iowa legislature also enacted a law entitled "An Act to prevent trespass and other injuries being done to the possession of settlers on the public domain, and to define the extent of the right of possession on said lands." This act further provided that no elaim should be for a tract greater than 320 acres or less than 40 acres, and that the owner of such claim could not neglect it for a period of six months or more without losing his right to it. It is to be noted that these statutes made no attempt to pass the title of the land, but that both of them were in conflict with the federal law of 1507 .

This conflict gave rise to litigation in the territorial courts, of which the ease Hill vs. Smith is a significant illustration. It was tried in the Supreme Court of the Territory in July, 1840. The opinion was handed down by Judge Charles Mason, Chief Jusice of the Supreme Court of the Territory of Iowa, and is found in Morris' Reports, page 70. "Smith had sold Hill a 'claim' and taken a note for $\$ 1,000$, dated January 23, 1837. Smith had sued Hill in the lower court and obtained judgment. The case was carried to the Supreme Court, Hill arguing, (1) 'That the note was given for a contract for the purchase of a claim to a tract of the United States lands with the improvements thereon in violation of the provisions of the several acts of Congress upon that subject; (2) That the whole contract for which said writing obligatory was given is contrary to the laws of the United States, and is therefore void'." In writing his opinion Mason argued: "But the act of Congress of 1807 seems to have been intended merely to prevent the aequirement of title by oceupancy and to authorize the removal of intruders in those eases where public policy should require; but never to disturb the peaceable and industrious, whose labor was adding so much to the publie wealth, changing the barren wilderness into fertile fields." Further, he said, in conclusion, "We pronounce it contrary to the spirit 
of that Anglo-Saxon liberty, which we inherit, to revive without notice, an obsolete statute, one in relation to which long disuse and a contrary policy had induced a reasonable belief that it was no longer in force. If custom can make laws, it can, when long acquieseed in, recognized and countenanced by the sovereign power, also repeal them." Therefore, Mason perorated, "the act of March 3, 1807, so far as it would have gone to authorize the removal of the inhabitants of this Territory, or their punishment as eriminals, is wholly inoperative and void; that it has been repealed by long non user.",

As Professor Macey commented, "his decision may be flimsy law, but it is first class history.',

\section{Organizing the Territorial Government}

While the land surveys were being made, the country continued to receive settlers. On June 12, 1838, the President of the United States approved an act of Congress entitled, "An Act to divide the Territory of Wisconsin, and to establish the Territorial government of Iowa." The act provided that after the third day of July, 1833, " all that part of the present territory of Wisconsin which lies west of the Mississippi River and west of a line drawn due north from the headwaters or sources of the Mississippi to the territorial line, shall, for the purposes of temporary government, be and constitute a separate territorial government, by the name of Iowa." The act further provided that "nothing in this act contained shall be construed to impair the rights of person or property now appertaining to any Indians within the said Territory, so long as such rights shall remain unextinguished by treaty between the United States and such Indians, or impair or anywise to affect the authority of the government of the United States to make any regulations respecting such Indians, their lands, property, or other rights, by treaty, or law, or otherwise, which it would have been competent to the government to make if this act had never been passed."

It also earried a provision that one or more territories could be made out of this area to be known as the Territory of Iowa, which under this act eontained 194,381 square miles, made up as follows: 
Area of present State

56,147 square miles

Now in South Dakota east of the Missouri River

35,472 square miles

Now in North Dakota east of the Missouri and White Earth Rivers

48,030 square miles

Now in Minnesota west of the Mississippi River

54,732 square miles

194,381 square miles

Reduction of 1846 , all outside of present area. This was unattached until added to the Territory of Minnesota in 1849 ... 138,234 square miles

Area of State December 28, 1846 56,147 square miles (55,586 land; 561 water)

A study of this act ereating the Territory of Iowa shows some interesting things. It provided for a governor who should hold office for three years, subject to removal by the President of the United States. His powers and duties were defined as follows: "The governor shall reside within the said Territory, shall be the commander-in-chief of the militia thereof, shall perform the duties and receive the emoluments of the superintendent of Indian affairs, and shall approve of all laws passed by the Legislative Assembly, before they shall take effect;" he could grant pardons for offences against the laws of the territory, and reprieves for offenees against the laws of the United States, subject to, however, "the decision of the president." The governor was to call the legislative assembly into its first session at such time and place as he directed; he and the legislative assembly were charged with the duty, in the first session or as soon thereafter as possible, of locating and establishing a seat of government for the territory, which place of government could, however, be changed later by the governor and the legislative assembly.

In his dual eapacity he received $\$ 1,500.00$ annually as governor of the territory, and as Superintendent of Indian Affairs, $\$ 1,000.00$ annually, in addition. Since Indian affairs and the title to the land were two pressing problems, the governor had a busy time.

The act further provided for a secretary of the said territory, who should hold his office for four years unless removed 
by the president. In case of the death, removal, resignation or necessary absence of the governor from the territory, the secretary was required to act and perform all the duties that the governor would perform, etc.

The legislature was to consist of a legislative assembly composed of a Council of thirteen members who served for two years, and a House of Representatives, composed of 26 members, who served for a term of one year. The members of the legislative assembly were to be apportioned by the governor as nearly as practicable among the several counties in the ratio of population (Indians excepted), as established by a census for which the organic act made provision.

Restrictions were put upon the powers of the legislature; thus, the territorial legislative assembly could pass no law interfering with the primary disposal of the soil, nor could it levy a tax upon the property of the United States. It was forbidden to pass a law that would tax the lands or other property of non-residents higher than the lands of residents. Finally, to make them legal, the Congress of the United States had to approve all of the laws passed by the assembly and approved by the governor.

A system of courts was set up beginning with the justices of the peace and ending with the supreme court, the justices of which were appointed by the president, who also appointed the attorney of the territory and the marshall. All the presidential appointees were subject to removal by the president.

The organic act appropriated the sum of $\$ 20,000$ to the Territory of Iowa, to be used by the governor and the legislative. assembly of the territory to defray the expenses of erecting public buildings at the seat of government.

Every free white male above the age of twenty-one years "who shall have been an inhabitant of said Territory at the time of its organization shall be entitled to vote at the first election," if such white male was a citizen of the United States. The voters of the territory besides electing members of the legislature were also to elect a delegate to the House of Representatives of the United States Congress. He had no vote, but was privileged to speak on the affairs relating to the territory. 
Section 18 of this organie act is of more than passing interest and is printed here in full.

And be it further enacted, That the sum of five thousand dollars be, and the sum is hereby, appropriated, out of any money in the Treasury not otherwise appropriated, to be expended by, and under the direction of, the Governor of said Territory of Iowa, in the purchase of a library, to be kept at the seat of government for the accommodation of the governor, legislative assembly, judges, secretary, marshall, and attorney of said Territory, and such other persons, as the governor and legislative assembly shall direct.',

Congress by this appropriation started a state library which is still in existence. Moreover the fact that a state library was established speaks well for the literacy of the residents of the territory at that time.

There was some delay in appointing a governor of the Territory of Iowa, but Robert Lucas received the appointment from President Martin Van Buren on July 7, 1838. He had had much experience with men and in governmental affairs, having been a commissioned officer in the American army during the War of 1812-15, and had also seen Indian fighting. In governmental affairs he had experience both as legislator and governor, having served in both branches of the legislature of Ohio and two terms as governor of that state. Thus President Van Buren appointed a man as governor of the Territory of Iowa who had had experience in Indian affairs, in state boundary line disputes, and in military affairs. Iowa owes much to Robert Lucas.

William B. Conway had previously been appointed as Secretary of the Territory, and Charles Mason as Chief Justice of the Supreme Court.

On his way to Iowa Governor Lueas stopped at Cincinnati and there met a young man named T. S. Parvin, whom he appointed as his personal secretary and later as state librarian. Mr. Parvin became one of Iowa's truly great men and it was given to him to exert a great influence in the state of Iowa for many years. Governor Lueas took his office August 15,1838 , at Burlington. His first official act was to issue a proclamation on that same day dividing the territory into eight representative districts and apportioning the members of the House and Council among the respective counties. 
At the election that followed, William W. Chapman was elected Delegate from the territory to the House of Representatives of the United States. The members of the Council elected were as follows:

Jesse B. Brown, from the county of Lee.

E. A. M. Swazy and Isham Keith, from the county of Van Buren. Lawson B. Hughes and Jesse D. Payne, from the county of Henry.

Arthur Inghram, Robert Rolston, and George Hapner, from the county of Des Moines.

James M. Clark, from the counties of Muscatine, Louisa and Slaughter (Washington). Linn.

Charles Whittlesey, from the counties of Johnson, Cedar, Jones, and

Jonathan W. Parker, from the counties of Scott and Clinton.

Warner Lewis and Stephen Hempstead, from the counties of Jackson, DuBuque, and Clayton.

The members of the House of Representatives were as follows:

William Patterson, Hawkins Taylor, Calvin L. Price and James Brierly, from the county of Lee.

James Hall, Gideon S. Bailey and Samuel Parker, from the county of Van Buren.

William G. Coop, William H. Wallace and A. B. Porter, from the county of Henry.

James W. Grimes, George Temple, Van B. Delashmutt, Thomas Blair, and Cyrus S. Jacobs, from the eounty of Des Moines.

John Frierson, William L. Toole, Levi Thornton, and S. C. Hastings, from the counties of Museatine, Louisa and Slaughter (Washington).

Robert G. Roberts, from the counties of Cedar, Jones, Linn, and Johnson.

Laurel Summers and Samuel R. Murry, from the eounties of Seott and Clinton.

Chauncey Swan, Andrew Bankson, Thos. Cox and Hardin Nowlin, from the eounties of Jackson, DuBuque and Clayton.

With the appointment of all the officers provided for by the organic act and with this election of the legislative assembly, the civil government of the Territory of Iowa was under way. 
Copyright of Annals of Iowa is the property of State of Iowa, by \& through the State Historical Society of Iowa and its content may not be copied or emailed to multiple sites or posted to a listserv without the copyright holder's express written permission. However, users may print, download, or email articles for individual use. 